\title{
Linking temporal scales of suspended sediment transport in rivers: towards improving transferability of prediction
}

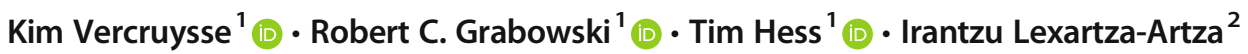

Received: 9 December 2019 / Accepted: 17 May 2020 / Published online: 29 May 2020

(C) The Author(s) 2020

\begin{abstract}
Purpose Suspended sediment (SS) transport in rivers is highly variable, making it challenging to develop predictive models that are applicable across timescales and rivers. Previous studies have identified catchment and hydro-meteorological variables controlling SS concentrations. However, due to the lack of long-term, high-frequency SS monitoring, it remains difficult to link SS transport dynamics during high-flow events with annual or decadal trends in SS transport. This study investigated how processes driving SS transport during high-flow events impact SS transport dynamics and trends observed over longer timescales.

Methods Suspended sediment samples from the River Aire (UK) (1989-2017) were used to (i) statistically identify factors driving SS transport over multiple timescales (high-flow events, intra- and inter-annual) and (ii) conceptualize SS transport as a fractal system to help link and interpret the effect of short-term events on long-term SS transport dynamics.

Results and discussion Antecedent moisture conditions were a dominant factor controlling event-based SS transport, confirming results from previous studies. Findings also showed that extreme high-flow events (in SS concentration or discharge) mask factors controlling long-term trends. This cross-timescale effect was conceptualized as high fractal power, indicating that quantifying SS transport in the River Aire requires a multi-timescale approach.

Conclusion Characterizing the fractal power of a SS transport system presents a starting point in developing transferrable process-based approaches to quantify and predict SS transport, and develop management strategies. A classification system for SS transport dynamics in river systems in terms of fractal power could be developed which expresses the dominant processes underlying SS transport.
\end{abstract}

Keywords Fractals $\cdot$ Process interactions $\cdot$ River Aire $\cdot$ Connectivity

\section{Introduction}

Suspended sediment (SS) transport in rivers is extremely variable in space and time. The amount of SS in a river is controlled by a complex system of geomorphological and

Responsible editor: Simon Pulley

Electronic supplementary material The online version of this article (https://doi.org/10.1007/s11368-020-02673-5) contains supplementary material, which is available to authorized users.

Kim Vercruysse

kim.vercruysse@cranfield.ac.uk

1 Cranfield Water Science Institute, School of Water, Energy and Environment, Cranfield University, Cranfield MK43 0AL, UK

2 Arup, Rose Wharf, 78 East Street, Leeds LS9 8EE, UK hydrological processes and process interactions over multiple scales (McDonnell et al. 2007; Onderka et al. 2012; Bracken et al. 2015; Vercruysse et al. 2017). This complexity makes it challenging to adequately quantify and predict SS transport (Phillips 2003; Gao 2008; Raven et al. 2010; Rickson 2014; Ahn et al. 2017). Yet, quantifying and predicting SS concentrations (SSC) in rivers has become a necessity, because, despite being a fundamental part of river systems, anthropogenic activities have altered sediment transport processes in most rivers leading to significant management problems. Excess fine sediment in rivers can cause ecological degradation, water quality decline (with higher associated water treatment costs), increased flood risk, and infrastructural damage (Owens et al. 2005; Bilotta and Brazier 2008; Horowitz 2009; Taylor and Owens 2009; Bilotta et al. 2012). Prediction of SS transport is essential to develop well-informed management policies but requires a thorough understanding of the timescale 
dependency of erosion and transport processes operating in the catchment and river network.

The SS in rivers represents a mixture of fine $(<63 \mu \mathrm{m})$ organic and inorganic particles originating from land, caused by soil erosion (e.g. rill or gully erosion) (Morgan 2005), mass movements (e.g. riverbank erosion or landslides) (Vanmaercke et al. 2016), and/or human activity (e.g. road construction, sewage treatment works) (Taylor and Owens 2009). Therefore, the average SSC at a point in the river depends on hydrological, topographical, geological, climatic, and land cover characteristics of a catchment (Vercruysse et al. 2017). For example, these factors determine the vulnerability of the soil to erosion (e.g. degree of vegetation cover), the risk of mass movements (e.g. combination of topography and saturated soils), the contribution of different sources (e.g. agricultural versus urban land), and the sediment connectivity of a catchment (i.e. the degree to which the efficiency of spatial sediment transfer is limited due to catchment characteristics and transport processes) (Fryirs 2013; Bracken et al. 2015). Simultaneously, SSCs vary over time due to the interaction of hydro-meteorological processes, sediment source contributions, and landscape disturbances (natural and human; Vercruysse et al. 2017), by controlling surface runoff (e.g. increased soil erosion due to decreased soil infiltration capacity; Seeger et al. 2004; Smith and Dragovich 2009), sediment connectivity (e.g. connecting distant SS sources to the river after prolonged rainfall; Croke et al. 2013), sediment supply (e.g. exhaustion of supply or riverbank collapse; Aich et al. 2014), and/or sediment production (e.g. seasonal vegetation growth protecting soil from erosion; Sun et al. 2016).

Following identification of a range of factors and processes underlying spatiotemporal variation in SSCs, process-based models have been developed which are able to predict SS transport at different spatial and temporal scales, by combining mathematical expressions that represent both hillslope processes (soil erosion and delivery to the river channel) and in-channel processes driven by streamflow (Gao 2008). Nevertheless, it remains challenging to link processes controlling variation in SS transport across multiple timescales (Blöschl 2006; Vercruysse et al. 2017). This challenge is mainly related to the difficulty of representing processes producing SS from point sources (e.g. bank erosion and channel beds) and the complex interactions and feedback mechanisms between hydrologic and erosion processes (Gao 2008; Ahn et al. 2017).

To this end, concepts such as sediment connectivity (Fryirs 2013; Bracken et al. 2015) or landscape metrics (Van Nieuwenhuyse et al. 2011) have been used to synthesize dominant processes underlying soil erosion and sediment transport over multiple spatial scales. At the temporal level, the idea of "effective timescales of connectivity" has been used to define the timeframe over which sediment (dis)connectivity occurs, whereby parts of the catchment are "switched on and off" as a response of events with varying frequency-magnitude relationships (e.g. rare storm events versus land use change) (Harvey 2002; Fryirs 2013). Similarly, "characteristic timescales" are used in different scientific disciplines to address variability across different scales, which involves identifying lengths of time that are representative for particular processes (Skøien et al. 2003).

These concepts provide excellent frameworks to understand temporal variability and identify relevant timescales for sediment transport, but do not unify the underlying mechanisms for temporal variability in SS transport (Blöschl 2006; Vercruysse et al. 2017). The complexity and scale dependency of processes driving SS transport stress the need to decipher how sediment generation, storage, and transport are linked across different timescales, i.e. to assess and predict the spatiotemporal impact of short-term events (e.g. bank collapse) on long-term (annual to decadal) trends in SS transport. To this end, we argue that it may be useful to consider SS transport as a fractal system (Halley et al. 2004). Fractals are used to describe and predict patterns over different spatial or temporal scales in scientific disciplines such as catchment hydrology, (fluvial) geomorphology, geography, and ecology (Rodriguez-Iturbe and Rinaldo 2001; Sivakumar 2001; Skøien et al. 2003; Halley et al. 2004; Van Nieuwenhuyse et al. 2011; Jiang and Brandt 2016; Medina-Cobo et al. 2016), but have not been specifically applied to describe dynamics in SSCs. By approaching SS transport dynamics as a fractal system, it is assumed that patterns of variation in SS transport exist over different timescales (Fig. 1), while linkages across those temporal scales are expressed as fractal power. Fractal power represents the ratio of large-scale variability and small-scale variability and implies that if the small-scale variability in time is very high, it strongly affects the observed large-scale variability and trends (Skøien et al. 2003). In systems with low fractal power, the long-term driving processes are dominant and are visible at smaller scales (e.g. overall higher SSCs as a result of deforestation; Walling 2009), while in systems with high fractal power, long-term variation is muted by processes over shorter timescales (e.g. SS transport driven by storm events in badland region with a high sediment supply; Francke et al. 2008, Francke et al. 2014). Insights into the degree of fractal power of a SS transport system may provide a useful basis to evaluate and develop the most appropriate predictive models and management strategies.

A better understanding of the mechanisms driving variation in SS transport and how these mechanisms link across temporal scales is essential to the development of transferable process-based approaches to quantify SSCs and, in turn, targeted management strategies. Therefore, this study investigated how processes driving SS transport over short timescales (i.e. high-flow events) impact SS transport dynamics and trends observed over longer timescales. The catchment of the River Aire (UK) was used as a case study to (i) identify dominant factors and mechanisms driving SS transport at 
Fig. 1 Temporal variability in suspended sediment transport exhibits different degrees of fractal power: low fractal power means that processes at the intraannual and event timescales do not mute the long-term processes; high fractal power means that seasonal and event dynamics significantly impact variations at the inter-annual scale. Numbers 1, 2 , and 3 represent individual years

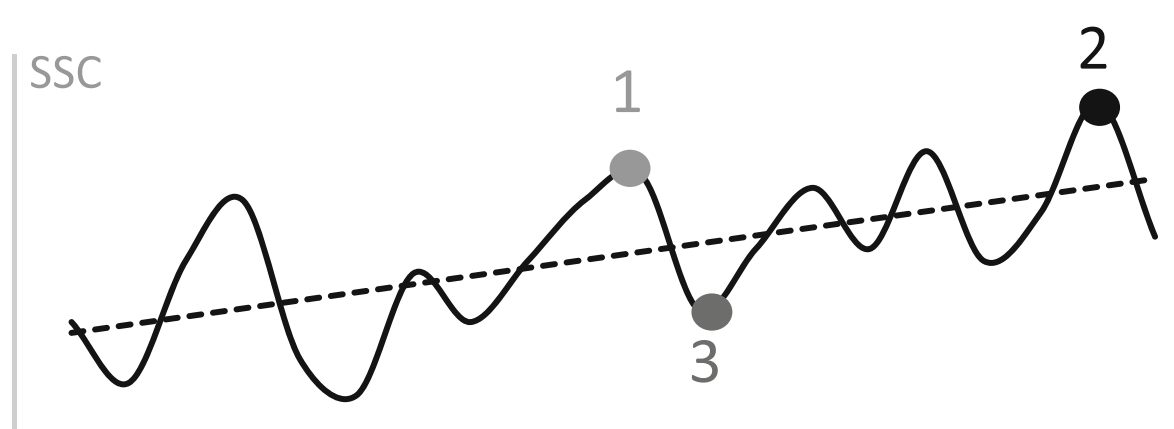

Years

\section{Low fractal power}
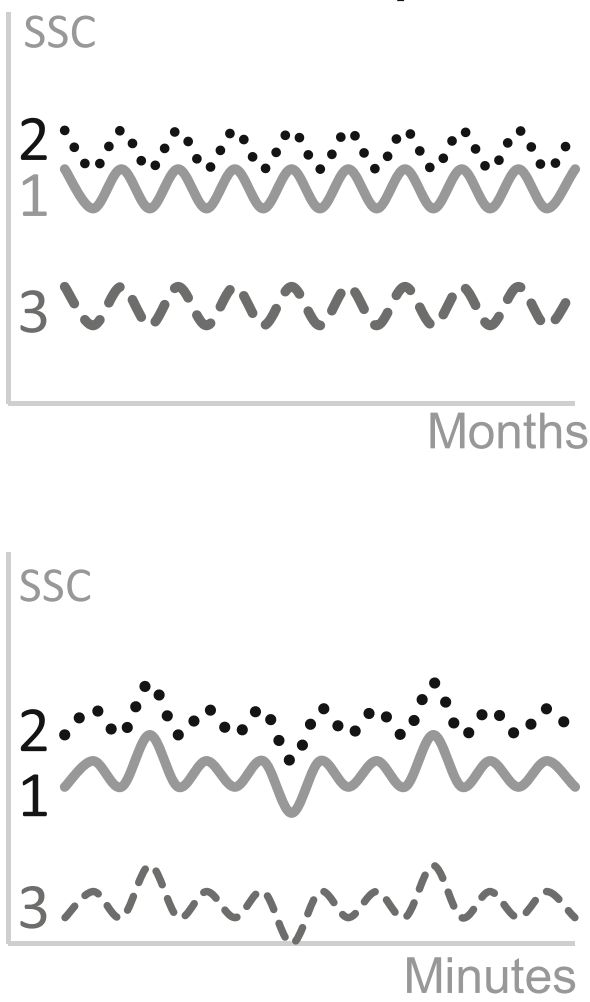

\section{High fractal power}
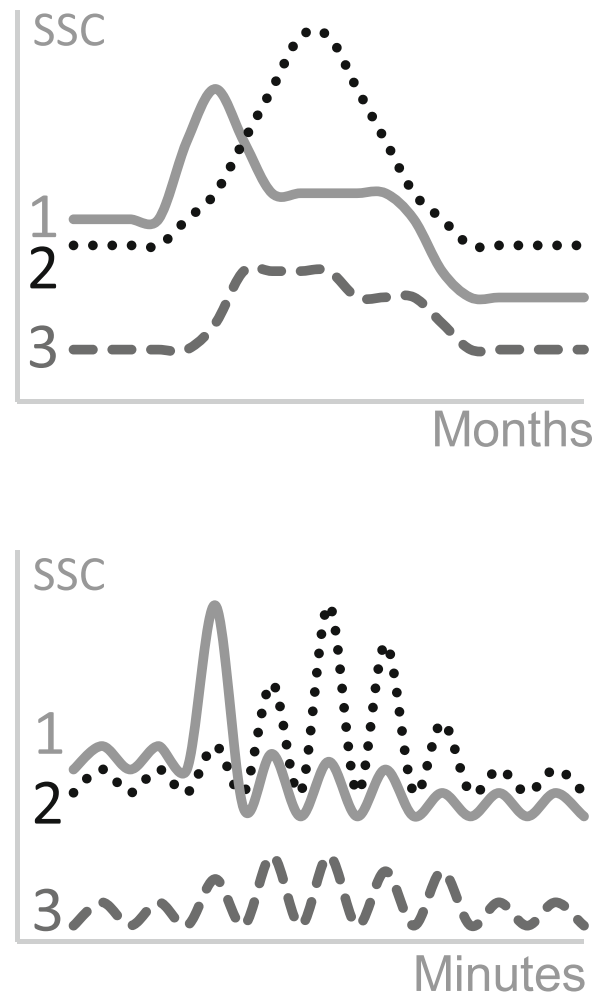

three timescales (high-flow events, intra-annual, inter-annual) and (ii) conceptualize SS transport as a fractal system to help link and interpret the effect of short-term events on long-term SS transport dynamics.

\section{Materials and methods}

\subsection{Study area}

The River Aire rises in North Yorkshire (200 m AOD) and continues for $70 \mathrm{~km}$ until it reaches the city of Leeds $(26 \mathrm{~m}$ AOD) (Fig. 2). Upstream of Leeds, the River Aire has a total catchment area of $690 \mathrm{~km}^{2}$ and is composed of three main Carboniferous geologies: limestone and shale formations in the upper part, Millstone Grit (sandstone) in the middle part, and coal measures (siltstone, mudstone, and sandstone) in the lower part (Morton et al. 2011) (Fig. 2). The soils are predominantly loamy to clayey with a diversity that includes raw oligo-fibrous peats and stagnohumic and stagnogley soils in the upper catchment and brown earths and pelo-stagnogley soils in the middle and lower parts (Carter et al. 2006). Land use in the catchment is dominated by grassland $(59 \%)$ and urbanized areas $(25 \%)$, while the remaining part of the catchment is characterized by heath with peat bogs in the highest parts $(12 \%)$ and scattered arable land $(4 \%)$.

Median daily flow $\left(Q_{50}\right)$ of the River Aire in Leeds is $10 \mathrm{~m}^{3} \mathrm{~s}^{-1}$, while there is a $10 \%$ probability of discharges exceeding $40 \mathrm{~m}^{3} \mathrm{~s}^{-1}\left(Q_{10}\right)$. Annual precipitation rates vary between 600 and $1500 \mathrm{~mm}$, with a mean of $1050 \mathrm{~mm}$ for the available data. 


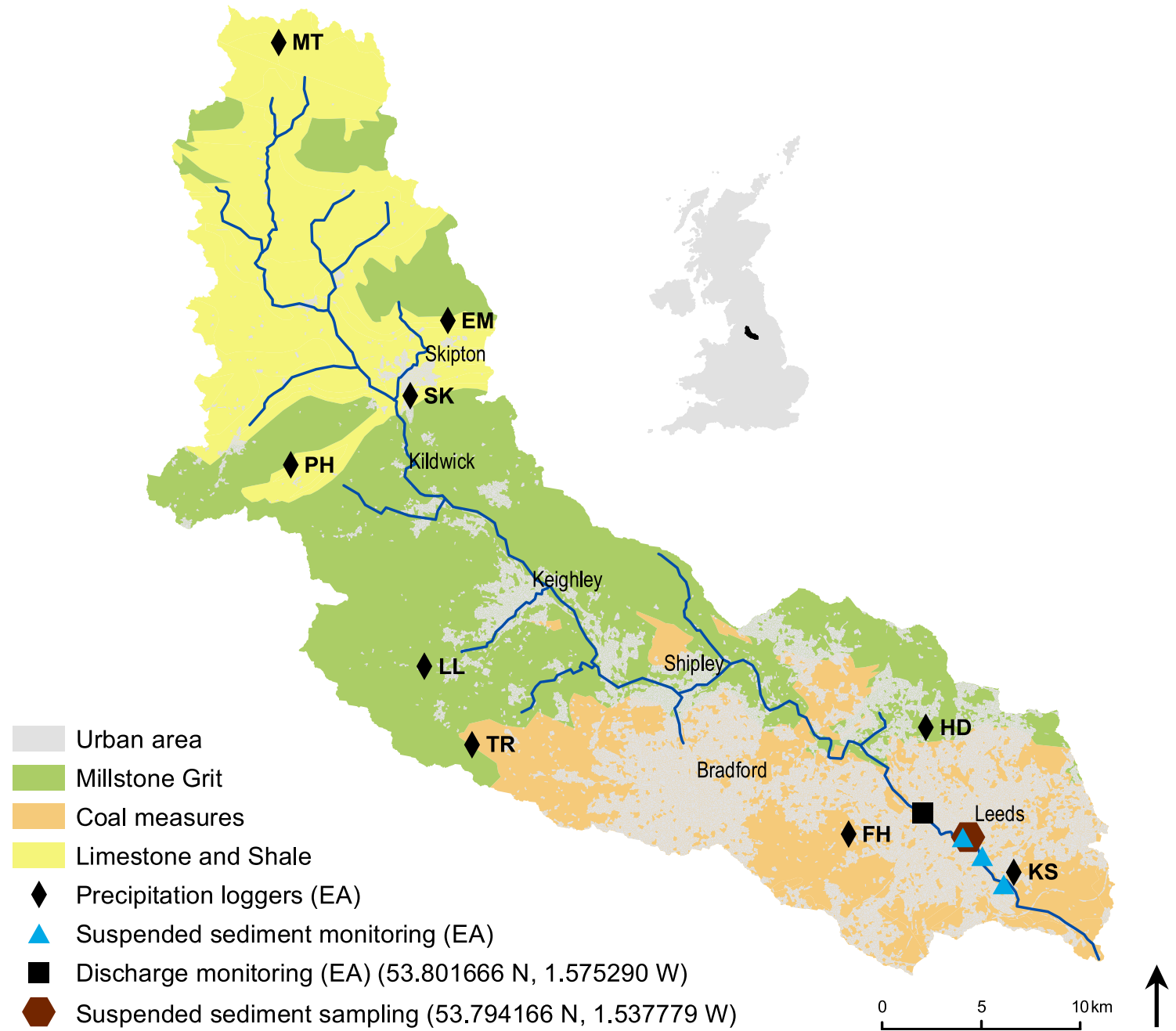

Fig. 2 The River Aire catchment (UK): geology, urban land cover, and locations of monitoring and sampling (MT Malham Tarn, EM Embsay, PH Proctor Heights, SK Skipton, SR Silsden Reservoir, LL Lower

\subsection{Data}

\subsubsection{Suspended sediment data}

To capture SS transport dynamics at multiple timescales (events, inter- and intra-annual), two data sources of SSC were used. First, SS samples were collected with a depthintegrating SS sampler during 14 precipitation events (200 samples) between June 2015 and March 2017 at a single location within the city centre (Fig. 2, Table 1). Second, SSCs were obtained from three monitoring stations within the city of Leeds from the Environment Agency (EA) (1989-2014; after 2014 no monitoring data for the same locations is available) (Fig. 2). The EA dataset is based on discrete monthly samples (i.e. 1 sample per month) collected as part of routine water quality monitoring. In both cases, sediment samples were obtained by filtration of a measured volume of water on pre-dried and pre-weighed filters. Event-based samples
Laithe, TR Thornton Reservoir, FH Farnley Hall, HD Headingley, KS Knotstrop) (land cover data derived from LCM 2007 (Morton et al. 2011))

were filtered through pre-weighed glass/quartz fibre filters (pore size $=1 \mu \mathrm{m}$ ), then dried for $2 \mathrm{~h}$ at $105^{\circ} \mathrm{C}$ before being weighed. The SSC datasets of the three EA monitoring stations contain gaps in the time series. To fill these gaps, SSC values from the three stations were averaged to construct a single SSC time series for further analysis (Table 1).

\subsubsection{Hydro-meteorological data}

River discharge time series were obtained from the closest monitoring station (Fig. 2) to the manual SS sampling point: mean daily discharge data were downloaded from the National River Flow Archive (NRFA) (1961-2015) (National River Flow Archive 2017), and instantaneous discharge (15 min) was provided by the EA (2007-2017). From the same location, monthly precipitation measurements were obtained from NRFA (1961-2015). Additionally, 
Table 1 Suspended sediment concentration datasets: period, resolution, number of samples and source

\begin{tabular}{lll}
\hline & Event-based dataset & EA dataset \\
\hline Period & June 2015-March 2017 & 1989-2014 \\
Sample frequency & Hourly/30 min during high-flow events & Discrete monthly \\
Number of samples & 200 & 300 \\
Source & This study & Environment Agency (UK) \\
\hline
\end{tabular}

instantaneous precipitation data $(15 \mathrm{~min})$ were obtained (2015-2017) from 10 EA loggers across the catchment (Fig. 2).

\subsection{Data analysis}

The SSC and hydro-meteorological data were analysed over three timescales (i.e. high-flow event, intra-annual, and interannual) to assess patterns and trends in temporal variation and identify timescale-dependent factors controlling SSC.

\subsubsection{High-flow events}

The SSCs during high-flow events are known to be highly variable depending on variations in river discharge and rainfall conditions. To investigate how variation in discharge and precipitation influence SSCs in the River Aire, two approaches were used. First, hysteresis patterns between SSC and discharge were visually inspected in terms of shape (clockwise, counterclockwise, or complex) to assess the variable relationship between SSC and discharge during different highflow events, which provides a simple means to evaluate the presence of potential factors controlling SS transport (Tananaev 2015; Lloyd et al. 2016; Sherriff et al. 2016).

Second, a more complex multivariate approach was applied to (i) identify hydro-meteorological variables that are significantly correlated to the SSC and (ii) investigate the relationship between those variables and SSC over time. Precipitation and discharge data are often highly collinear, making a multiple linear regression unsuitable without an initial variable selection step. To address this, advanced data-mining techniques, e.g. fuzzy logic (Lohani et al. 2007) and artificial neural networks (Cobaner et al. 2009), have been successfully used to estimate SSCs as function of a range of variables. An alternative approach based on partial least squares regression (PLSR) was used in this study, which is able to handle data with strongly collinear variables, while also providing additional statistics on variable importance (Martens and Martens 2000; Wold et al. 2001; Karaman et al. 2013). The method works by projecting the data onto a new set of variables (components) similar to principal component analysis (PCA), but, instead of maximizing the variance within one dataset as in PCA, PLSR maximizes the covariance between two datasets based on the respective scores (Stevens and Lopez 2015). The multivariate dataset was divided into two parts: $75 \%$ for calibration and $25 \%$ for validation, randomly selected by a Kennard-Stone sampling algorithm. Leave-one-out cross-validation in the calibration phase was applied to determine the optimal amount of components based on the amount of components with the lowest root mean squared error (RMSE) (Martens and Martens 2000; Wold et al. 2001; Poulenard et al. 2009).

The PLSR scores and loadings were used to examine the importance of different hydro-meteorological variables in explaining the variation in SSC and how these vary over time (Martens and Martens 2000; Wold et al. 2001; Karaman et al. 2013). First, variables with large loadings (between -1 and 1) on a component are more correlated to that component. Therefore, the squared PLSR loadings (SSL) were used as a measure to evaluate which hydro-meteorological variables define the model components and thus are most significantly correlated to the SSC. Second, observations (measured SSCs) with a high score on a particular component are better explained by that component, so that the variation in scores can indicate how the importance of different components changes over time.

Previous studies that applied multivariate statistical techniques to quantify SSC based on hydro-meteorological data included variables such as antecedent soil moisture, rainfall intensity and duration, and air temperature, to account for the process interactions controlling SS transport in rivers (Kisi 2005; Lohani et al. 2007; Francke et al. 2008; Cobaner et al. 2009; Onderka et al. 2012). In this study, variables were selected based on the high-frequency (i.e. sub-daily) data sources available (instantaneous and antecedent discharge (1 h; 1, 7 and 21 days) and antecedent precipitation (1, 7 and 21 days)) from all monitoring stations (Table 2) and previous studies that used antecedent precipitation and discharge (7 and 21 days) as proxy variables for antecedent moisture conditions in the catchment (Lawler et al. 2006; Tena et al. 2014; Dominic et al. 2015; Perks et al. 2015; Lloyd et al. 2016; Zeiger and Hubbart 2016). The data of all ten rainfall gauges were used as individual variables, creating an extensive dataset of spatially distributed precipitation variables to investigate the impact of rainfall distribution across the catchment. 
Table 2 Sediment and hydro-meteorological variables per temporal scale

\begin{tabular}{|c|c|c|c|c|}
\hline Scale & Data & Variable & Unit & Description \\
\hline \multirow[t]{10}{*}{ Event } & \multirow[t]{9}{*}{ EA (2015-2017) } & Q & $\mathrm{m}^{3} \mathrm{~s}^{-1}$ & Instantaneous discharge (time of sampling) \\
\hline & & $Q_{1 \mathrm{~h}}$ & $\mathrm{~m}^{3} \mathrm{~s}^{-1}$ & Discharge $1 \mathrm{~h}$ prior to time of sampling \\
\hline & & $Q_{1 \mathrm{~d}}$ & $\mathrm{~m}^{3} \mathrm{~s}^{-1}$ & Discharge 1 day prior to time of sampling \\
\hline & & $Q_{7 \mathrm{~d}}$ & $\mathrm{~m}^{3} \mathrm{~s}^{-1}$ & Discharge 7 days prior to time of sampling \\
\hline & & $Q_{21 \mathrm{~d}}$ & $\mathrm{~m}^{3} \mathrm{~s}^{-1}$ & Discharge 21 days prior to time of sampling \\
\hline & & $P$ & $\mathrm{~mm}$ & Instantaneous precipitation (time of sampling) $(*)$ \\
\hline & & $P_{1 \mathrm{~d}}$ & $\mathrm{~mm}$ & Precipitation 1 day prior to event $(*)$ \\
\hline & & $P_{7 \mathrm{~d}}$ & $\mathrm{~mm}$ & Precipitation 7 days prior to event $(*)$ \\
\hline & & $P_{21 \mathrm{~d}}$ & $\mathrm{~mm}$ & Precipitation 21 days prior to event $(*)$ \\
\hline & Sampled (2015-2017) & SSC & $m g L^{-1}$ & Instantaneous SSC \\
\hline \multirow[t]{4}{*}{ Intra-annual } & NRFA + EA (1961-2014) & $Q$ & $\mathrm{~m}^{3} \mathrm{~s}^{-1}$ & Mean daily discharge per month (on days of SS samples) \\
\hline & NRFA + EA (1961-2014) & $P$ & $\mathrm{~mm}$ & Average total monthly precipitation \\
\hline & EA (1989-2014) & $\mathrm{SSC}$ & $\mathrm{mg} \mathrm{L}^{-1}$ & Mean monthly SSC \\
\hline & Sampled (2015-2017) & SSC & $\mathrm{mg} \mathrm{L}^{-1}$ & Mean monthly SSC \\
\hline \multirow[t]{3}{*}{ Inter-annual } & NRFA + EA (1961-2014) & $Q$ & $\mathrm{~m}^{3} \mathrm{~s}^{-1}$ & Mean daily discharge per year \\
\hline & NRFA + EA (1961-2014) & $P$ & $\mathrm{~mm}$ & Total annual precipitation \\
\hline & EA (1989-2014) & $\mathrm{SSC}$ & $\mathrm{mg} \mathrm{L}^{-1}$ & Mean annual SSC \\
\hline
\end{tabular}

*Variables calculated for each precipitation logger (10 in total, Fig. 2)

\subsubsection{Intra-annual}

Seasonal variation in SSC is often attributed to annual cycling in sediment transport and storage as a result of the interaction between changing hydro-meteorological conditions and vegetation (Vercruysse et al. 2017). To identify potential intraannual patterns, both the EA and sampled SSC data were merged into a single dataset to extend the EA dataset to 2017 (Table 1): average monthly SSCs were calculated along with average monthly discharges (measured on the days for which a SSC measurement is available) and average total monthly precipitation. The relationships between discharge and SSC, and precipitation and SSC, were assessed by visually examining mean monthly hysteresis patterns in terms of shape (clockwise, counter-clockwise, or complex) (Rovira et al. 2015; Sun et al. 2016).

\subsubsection{Inter-annual}

Finally, SSC can also vary or change over longer timescales (annual, decadal) as a result of gradual land use or climatological changes within the river catchment (Vercruysse et al. 2017). Therefore, mean annual SSC and discharge and total annual precipitation were also calculated based on the EA data (Table 1). To identify trends in each dataset, and to assess whether similar trends are present in both the annual hydrometeorological data and the SSC, the annual time series were analysed using (i) Pettitt's change point analysis to detect abrupt changes (Pohlert 2015; Sun et al. 2016) and (ii) a non-parametric Mann-Kendall test to detect the presence of gradual, monotonic trends (Zhang and Lu 2009; Zhang et al. 2009; Fan et al. 2012; Zhang and Mao 2015; Sun et al. 2016).

\section{Results}

\subsection{High-flow events}

The mean discharges of sampled high-flow events ranges from 9.4 to $72.3 \mathrm{~m}^{3} \mathrm{~s}^{-1}$ and the SSCs from 15.9 to $179.4 \mathrm{mg} \mathrm{L}^{-1}$, and are characterized by different hysteresis patterns between discharge and SSC as illustrated for three events in Fig. 3. The events in June 2015 and September 2016 had a similar hydrograph with peak discharges of approximately $40 \mathrm{~m}^{3} \mathrm{~s}^{-1}$ and both were characterized by counter-clockwise hysteresis between discharge and SSC. However, SSCs were significantly different; the September 2016 event reached an exceptionally high SSC peak of $1007.5 \mathrm{mg} \mathrm{L}^{-1}$ (Fig. 3b), compared with that of $151 \mathrm{mg} \mathrm{L}^{-1}$ in June 2015 (Fig. 3a). In November 2016, SSCs were comparable with that in the June 2015 event, but discharges were twice as high and the hysteresis pattern went in the opposite direction (i.e. clockwise; Fig. 3a, c).

The PLSR analysis performed on the event-based hydrometeorological and SSC dataset produced a PLS regression model with the lowest RMSE consisting of four components $\left(\mathrm{RMSE}=70 \mathrm{mg} \mathrm{L}{ }^{-1}, R^{2}=0.41\right.$; Fig. 4; Supplementary 
(a)

(b)

(c)

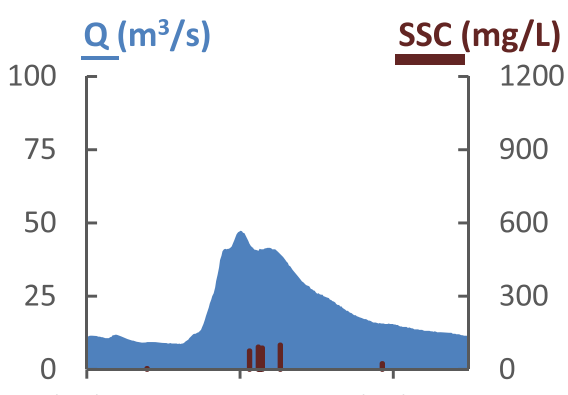

$01 / 06 / 2015$

03/06/2015

11:59
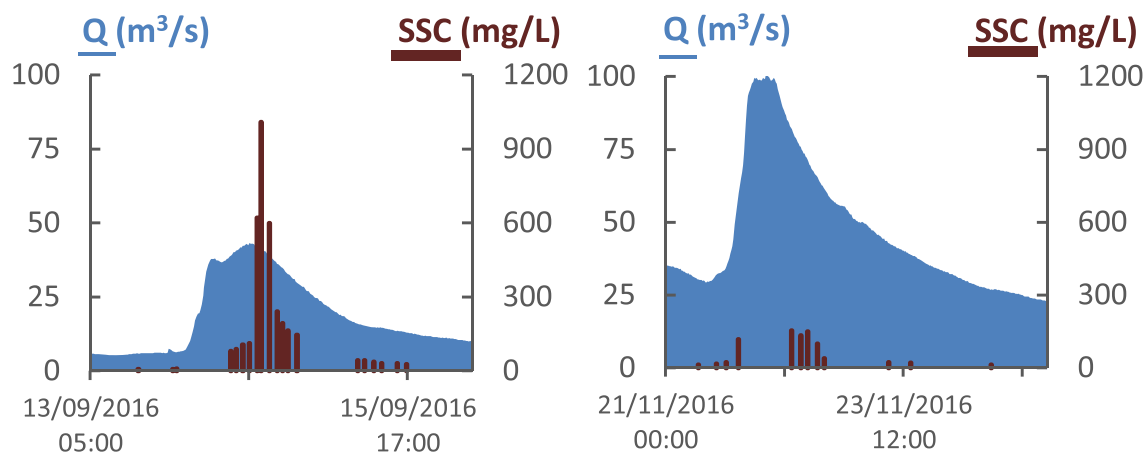

$Q\left(m^{3} / s\right)$

$\mathrm{SSC}(\mathrm{mg} / \mathrm{L})$
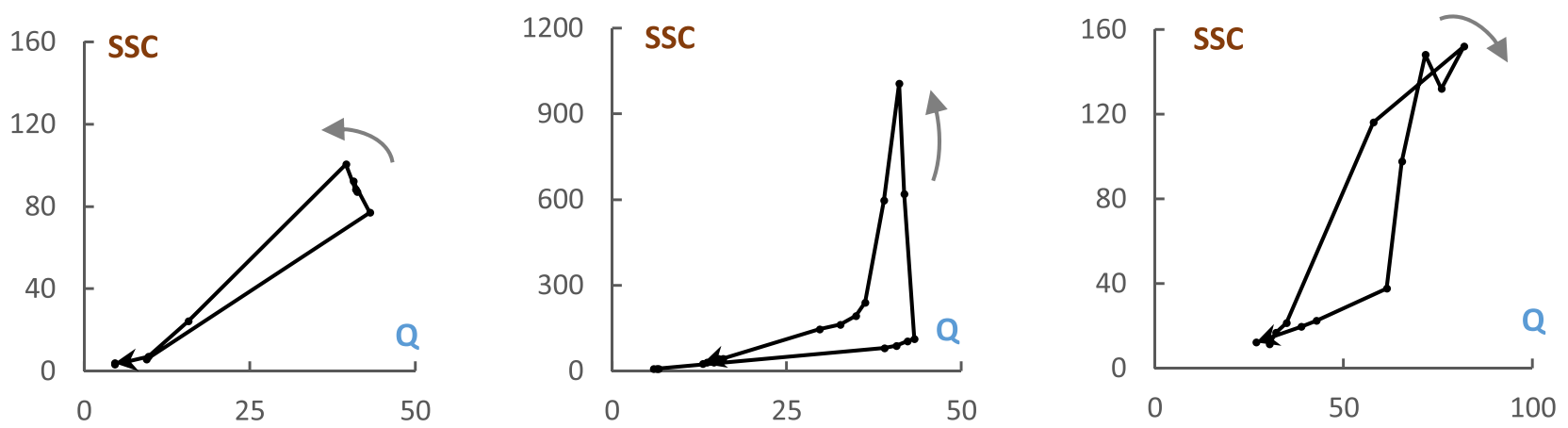

Fig. 3 Discharge $\left(Q\right.$ in $\left.\mathrm{m}^{3} \mathrm{~s}^{-1}\right)$ and SSC (in $\mathrm{mg} \mathrm{L}^{-1}$ ) of selected high-flow events in a June 2015, b September 2016, and c November 2016

material). The high RMSE was influenced by outliers caused by exceptionally high SSCs during an event in September 2016 (Fig. 3b). The four components explain $43 \%$ of the total variance in the $\operatorname{SSC}(15.5 \%, 14 \%, 8 \%$, and $5.5 \%$, respectively).

The squared PLSR loadings provide insights into which variables are most important in defining the PLSR components (Fig. 4a). The first component is mainly determined by $P_{1 \mathrm{~d}}$ (from all gauging stations), $Q$, and $Q_{1 \mathrm{~h}}$, while the second component is related to $P_{21 \mathrm{~d}}$ (from all gauging stations), $Q_{1 \mathrm{~d}}$, and $\mathrm{Q}_{7 \mathrm{~d}}$. The instantaneous precipitation variables from all gauging stations $(P)$ are generally included in the third component, and the fourth component is characterized by $P_{7 \mathrm{~d}}$ and $P_{21 \mathrm{~d}}$ (from all gauging stations).

Furthermore, the scores of the individual observations on the components quantify which component explains the most variation for a particular observation over time (Fig. 4b-d). In general, peak SSCs correspond with high scores on the first component $\left(P_{1 \mathrm{~d}}\right.$ and $\left.Q\right)$. The second component $\left(P_{21 \mathrm{~d}}\right)$ appears to be important throughout events, but especially at the start. The third component $(P)$ appears to vary strongly during events, suggesting a more episodic pattern. At the start of the first event in June 2016, the second and third components are most important in explaining the SSCs, while gradually the first component becomes dominant. In the November 16 series of events, the third component becomes more important towards the third SSC peak. Finally, on February 17, the first component is dominant during the first event, while the second component becomes more important afterwards. The fourth component is not discussed, given the low explained variance $(5.5 \%)$.

\subsection{Intra-annual}

Considerable intra-annual variation was observed in mean monthly discharge, precipitation, and SSC (Fig. 5a). In general, the mean monthly SSC fluctuates around $12-16 \mathrm{mg} \mathrm{L}^{-1}$, while the highest mean SSCs are observed in October, November, and December (mean $23 \mathrm{mg} \mathrm{L}^{-1}$ ). Similarly, mean monthly discharges are around $10 \mathrm{~m}^{3} \mathrm{~s}^{-1}$ from May to September and highest from October to March (on average $20 \mathrm{~m}^{3} \mathrm{~s}^{-1}$ ).

The relationship between mean monthly discharge and SSC is expressed as a clockwise hysteresis pattern, while a figure- 8 pattern was observed between the mean monthly precipitation and SSC (Fig. 4b, c). The SSC increases with increasing discharge and precipitation from August to December, while from January, SSCs and precipitation drop, and discharges remain high until March. From March to May, both SSC and discharge further decrease until July, while precipitation remains relatively constant. Based on this discharge SSC hysteresis pattern, four periods can be identified: (i) October-December with high discharge and high SSC; (ii) January-March with similar discharges but decreasing SSCs; (iii) April-June with low discharges and low 

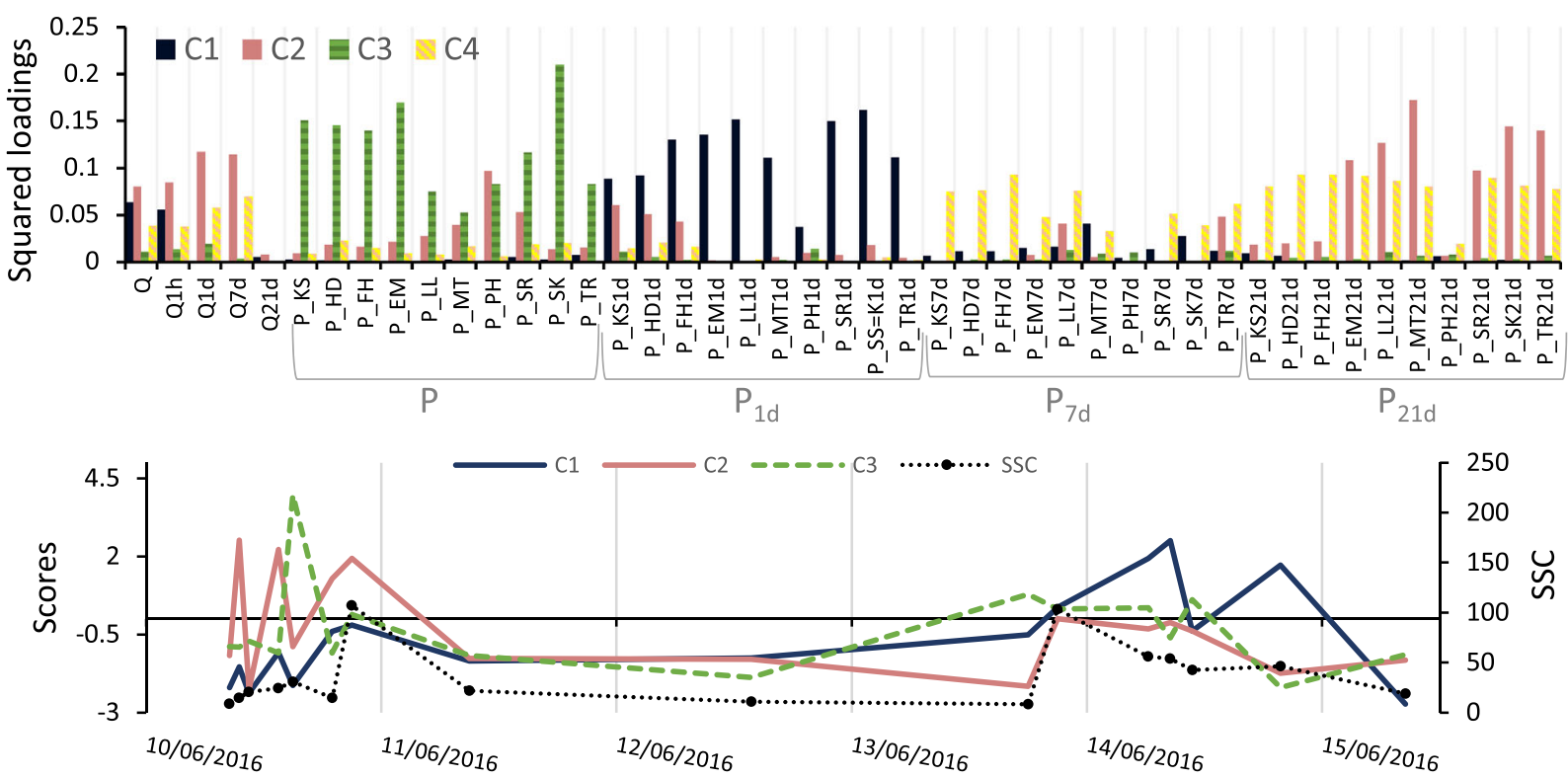

(b)

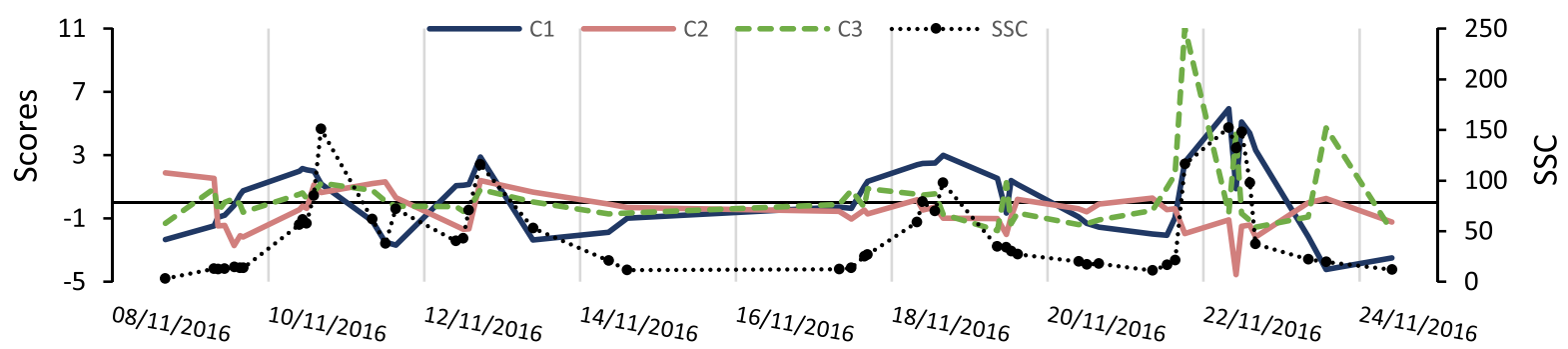

(c)

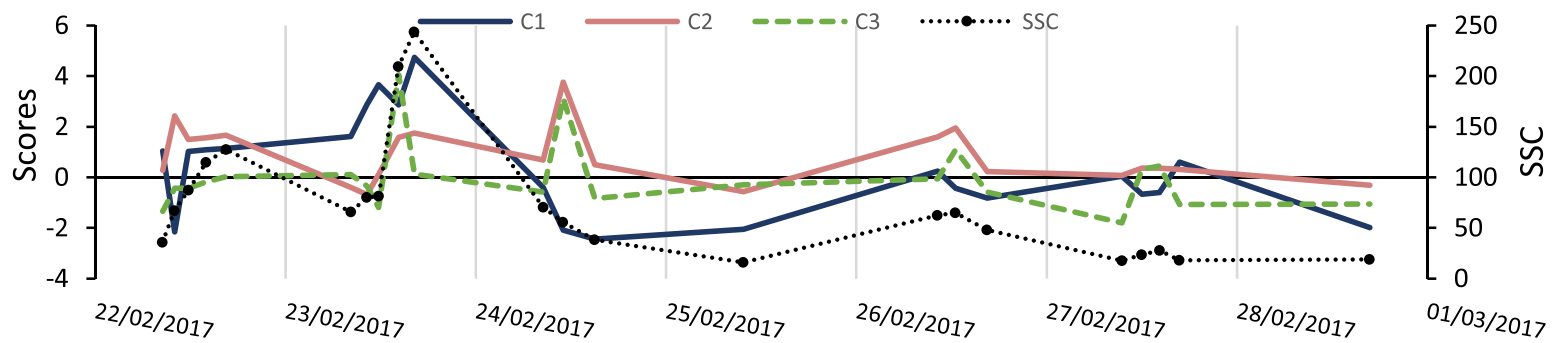

(d)

Fig. 4 PLS regression statistics: a squared PLS loadings for four components (C1 to C4). Observed SSCs and associated PLS scores on the first four components for a sequence of events in b June 2016, c November 2016, and d February 2017

SSCs; and (iv) July-September with low discharges but increasing SSCs.

\subsection{Inter-annual}

Discharge and precipitation exhibited strong inter-annual variation between 1961 and 2017 (Fig. 6). A significant change point in discharge was identified in $1980(p=0.039)$, marking a shift to a higher discharge period (1980-2017) in which the annual mean, maximum, and minimum discharge increased by $8 \%, 5 \%$, and $25 \%$, respectively, compared with that in 1961-1980. No change points were observed in the precipitation time series data, and no monotonic trends were detected in the annual discharge or precipitation data.
The SSC time series also shows strong inter-annual variation between 1989 and 2014. A significant change point is present in the SSC time series in $2006(p=0.006)$, whereby the mean SSC decreased by $14 \%$ between the pre- and post2006 period (Fig. 6). The Mann-Kendall test showed a significant decreasing trend in $\operatorname{SSC}(p=0.05)$.

\section{Discussion}

This study analysed SSCs in the River Aire over three timescales to uncover dominant processes and process interactions controlling temporal variation in SS transport. In what follows, the results are discussed in terms of the driving factors for temporal variation in SSCs during high-flow events, and 
Fig. 5 Monthly sediment and water dynamics: a mean discharge $\left(\mathrm{m}^{3} \mathrm{~s}^{-1}\right)(Q)$, mean suspended sediment concentration $\left(\mathrm{mg} \mathrm{L}^{-1}\right)(\mathrm{SSC})$, and precipitation $(\mathrm{mm})(P)$; the relationship between $\mathbf{b}$ mean monthly $Q$ and SSC and c mean monthly $P$ and SSC

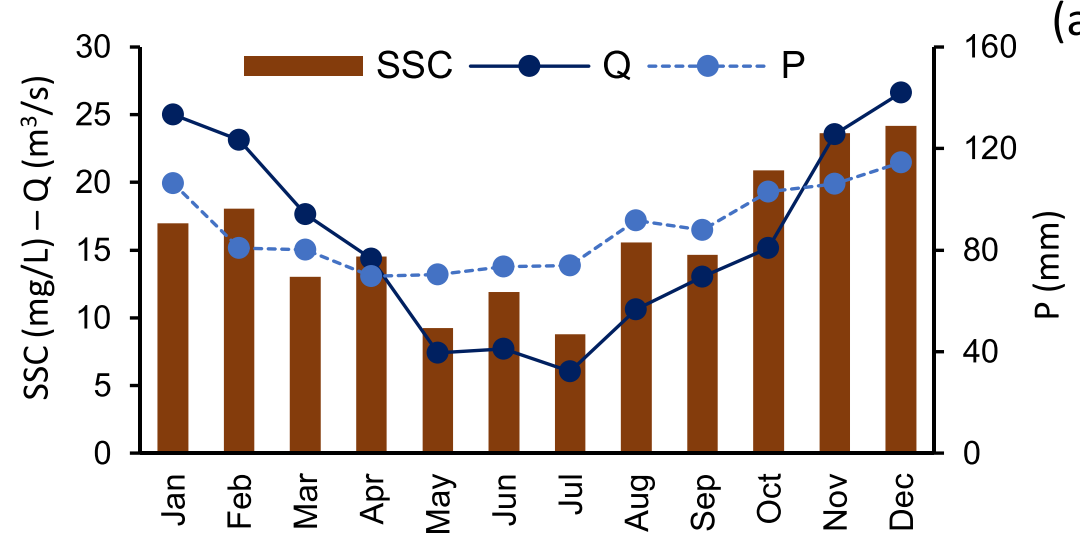

(a)

(c)
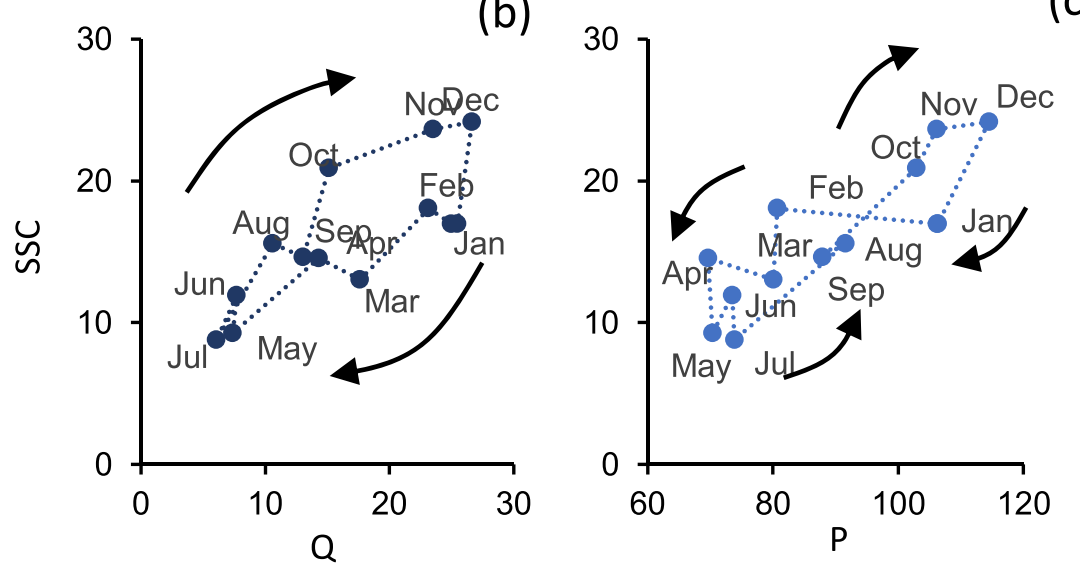

what those results imply for the interpretation of SS transport processes monitored over longer timescales. Finally, a conceptual framework is introduced to illustrate how sediment transport processes can be linked across timescales to improve the transferability of SS transport quantification and prediction.

\subsection{Mechanisms for temporal variation in suspended sediment transport}

\subsubsection{High-flow events}

The detailed hydro-meteorological data available at the event scale was used to identify variables that are correlated to SSC. In general, the results emphasize the importance of timing, frequency, and magnitude of precipitation events in controlling SSC in the river.

Consistent with previous research that demonstrated the importance of antecedent soil moisture conditions in controlling SSCs (McDowell and Sharpley 2002; Seeger et al. 2004; Smith and Dragovich 2009; Onderka et al. 2012; Tena et al. 2014), the results of the PLSR model suggest that discharge $(Q)$ and antecedent precipitation (1 and 21 days) explain the most variance in SSC (Fig. 4a). More specifically, antecedent precipitation (a proxy for antecedent soil moisture) and discharge at the time of sampling explain the most variance in SSCs (PLS component 1; Fig. 4a) but changes in the dominant component during and between events indicate important changes in the process interactions controlling SS transport. While PLS component 1 explains the most variance in SSC overall, other components explain more variance at different stages in the flood hydrograph. In most of the monitored events, component 2 correlates more strongly with SSC at the beginning of the flood hydrograph. Component 2 is mostly associated with precipitation 21 days prior to the event, reflecting the time required for sediment generation and transport overland caused by persistent rainfall before sediment particles are delivered to the river (Sherriff et al. 2016). Additionally, higher discharges within the channel after prolonged rainfall can also increase the shear stress of the river, resulting in (re)mobilization of bed material (Cao et al. 2007). A more episodic pattern in the importance of component 3 (precipitation at the time of sampling) was observed, which may indicate the impact of variations in rainfall intensity and/or patterns (Lexartza-Artza and Wainwright 2011). For example, the peak in component 3 in June 2016 on 10/ 06 at 15:00 h corresponds to exceptionally high precipitation intensities at TR and EM (5.4 and $3.6 \mathrm{~mm} / 15 \mathrm{~min}$ ). Similarly, 
Fig. 6 Annual time series of a discharge $(Q)$, b precipitation $(P)$, and $\mathbf{c}$ suspended sediment concentration (SSC). Grey dotted lines represent a linear regression and the vertical lines the Pettitt's change points in $Q\left(U_{\mathrm{Q}}\right)$ and $\mathrm{SSC}$ $\left(U_{\mathrm{SSC}}\right)$

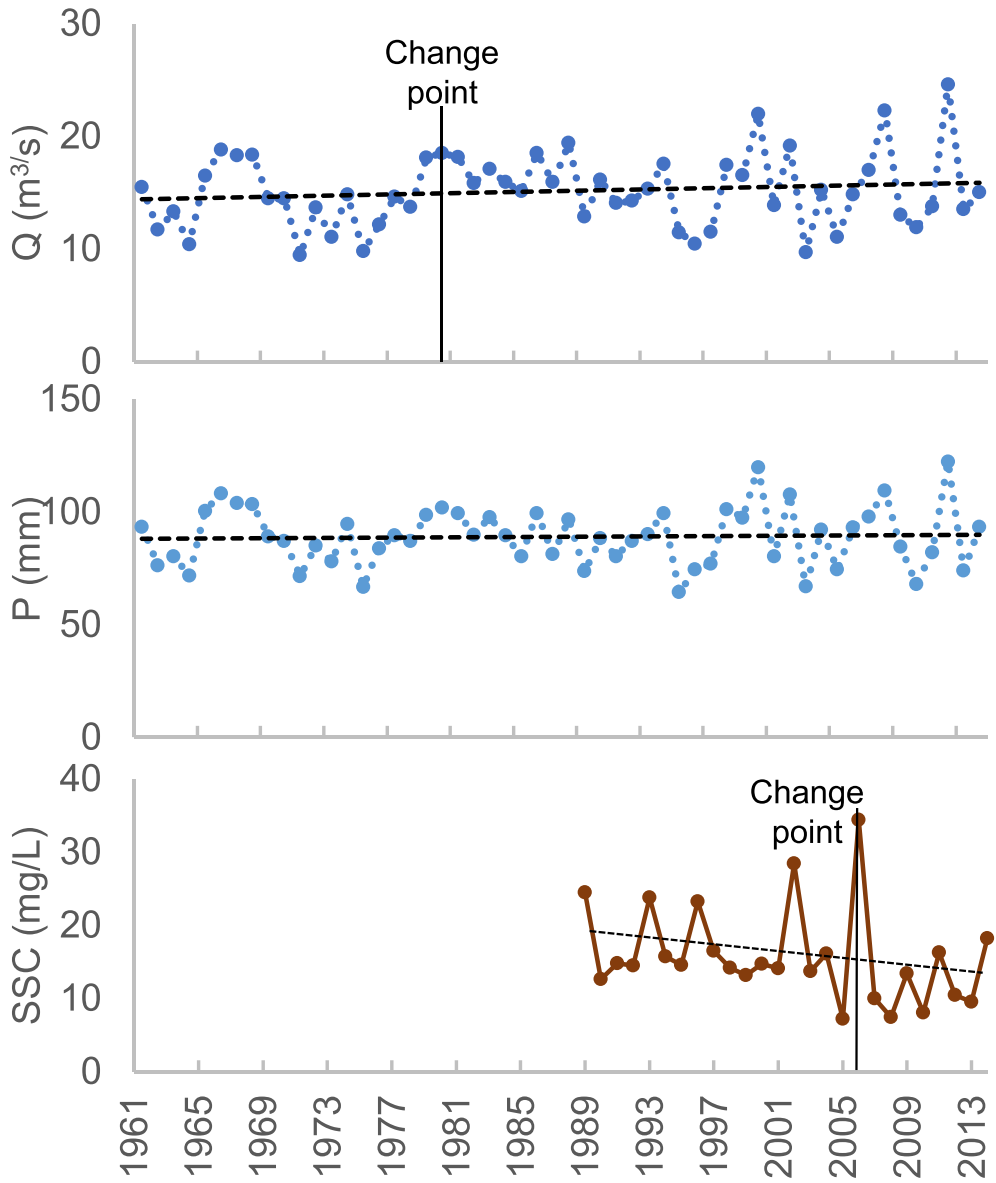

(a)

(b)

the peak in component 3 in November 2016 on 21/11 at $18: 15 \mathrm{~h}$ corresponds with precipitation intensities of $4.2 \mathrm{~mm} /$ $15 \mathrm{~min}$ at SK and $3.2 \mathrm{~mm} / 15 \mathrm{~min}$ at EM.

The patterns in component importance are illustrated well in the sequences of high-flow events in June and November 2016 (Fig. 4b-d). High-flow events in June 2016 were characterized by moderate peak discharges, but relatively high SSCs. During the start of the first event (Fig. 4b), PLS components 2 and 3 are most strongly associated with observed SSCs, indicating the importance of the interaction between antecedent moisture conditions and precipitation at the time of sampling. The drier period prior to the events in June 2016 could have led to drier soil surfaces that tend to repel water (hydrophobicity) and crust formation (surface sealing) at first rainfall impact. Soil crusting, in combination with possible soil compaction due to livestock (Bilotta et al. 2007), can reduce infiltration and lead to the generation of overland flow, which can (re)mobilize the sediment stored within the catchment, as well as increase the likelihood of interrill and gully erosion (Onderka et al. 2012). Furthermore, during the drying period, more urban street dust could have been built up on the streets and then washed away during the event (Old et al. 2003). This hypothesis is supported by findings from a sediment fingerprinting study applied to the SS samples collected during this event, which suggest that urban street dust and eroding grassland from the upper part of the catchment were dominant SS sources during the event (Vercruysse and Grabowski 2019). As the event progressed, component 1 became the dominant factor controlling SSC. This change can be an indication that soils were increasingly saturated, causing saturation excess overland flow to become the dominant process for erosion and SS transport to and into the river, and is supported by an increase in SS contribution from eroding grassland less connected to the river due to scattered urban areas (Coal Measures area, Fig. 2) (Vercruysse and Grabowski 2019). Similarly, prolonged precipitation in November 2016 (Fig. 4c), and associated saturation excess overland flow, may have caused more soil erosion and the connection of more SS sources to the river (Bracken et al. 2015). These findings also correspond to the sediment fingerprinting results, which indicate a decrease in contribution from eroding grassland from erodible areas (Limestone area) and an increase in contribution from less connected areas (Coal Measures area) as the events progressed (Vercruysse and Grabowski 2019). 
However, threshold behaviour appears to be present, in which increasing antecedent moisture conditions do not lead to linearly increasing SSCs. In February 2017 (Fig. 4d), component 1 is dominant at the start of the first event, while component 2 gains importance as the events progress, coinciding with a decrease in SSCs towards the second event (while discharges remain similar). This result could indicate a decrease in sediment supply (on the river bed and/or within the catchment) with increasing antecedent precipitation (i.e. soil saturation) (Krueger et al. 2009; Onderka et al. 2012).

The changing interplay between hydro-meteorological factors over time indicates that there are processes controlling SSC that operate over longer timescales than individual high-flow events, emphasizing the importance of monitoring intra-annual (seasonal) variability in SSCs.

\subsubsection{Intra-annual}

In general, the varying monthly SSC-discharge relationship (i.e. hysteresis; Fig. 5b) uncovers the interplay of natural and anthropogenic processes that control changes in catchment sediment supply and transport, which vary during and between events.

The excess or deficiency in SSC relative to discharge (i.e. deviation from a linear relationship between SSC and discharge) observed in the monthly hysteresis pattern helps to identify potential driving factors for seasonal variation in SS transport (Fig. 5). Similar to observations made in previous studies, the monthly hysteresis pattern suggests that the relationship between average discharge and SSC is not constant, which could be attributed to annual cycling of sediment controlled by seasonal variations in driving factors (Huisman et al. 2013; Park and Latrubesse 2014; Dominic et al. 2015; Rovira et al. 2015; Sun et al. 2016). From April to July, average SSCs are lowest (Fig. 5), which suggests that surface runoff and discharge are not sufficient to transport eroded material from the catchment towards and within the river. As a result, the readily available sediment (e.g. eroded material due to for example cattle trampling; Bilotta et al. 2007) is built up within the catchment and river network. When average discharges increase from August onwards, this material is mobilized, resulting in high SSCs with relatively low discharges. In OctoberDecember, average SSCs are highest, which could potentially be linked to increased soil erosion due to a decreased vegetation cover in autumn (Alexandrov et al. 2007). From January to March, average SSCs decrease while discharges remain high. This decrease in average SSCs could be caused by exhaustion of the sediment supply as the winter progresses into spring (Rovira et al. 2015; Sun et al. 2016) and/or changes in the sediment supply and connectivity of the catchment (Bracken et al. 2015) due to the growth of vegetation in spring in both agricultural and natural systems (i.e. protecting the soil from rainfall impact and enhancing infiltration) (Fryirs 2013).

\subsubsection{Inter-annual}

Besides variation in SSC during individual high-flow events and throughout the course of a year, many studies have also reported on long-term changes in SS transport caused by a range of factors such as land use change, climatic changes, dam construction, and other human activities within the catchment (Gregory 2006; Walling 2009; Belmont et al. 2011; Wohl 2015; Sun et al. 2016).

A previous study on the River Aire catchment estimated SS loads based on sediment cores and concluded that land cover has played an important role in controlling long-term variation in SS transport (Walling et al. 2003b). Between 1930 and 1950, an increase in SS load was attributed to the conversion of pasture to arable land during and shortly after World War II, while an increase since the mid-1970s was attributed to the conversion of moorland to pasture (Walling et al. 2003b). Those land use changes would have made the soil more vulnerable to erosion due to agricultural practices (e.g. tillage), the removal of a permanent vegetation cover, and soil compaction by livestock (Collins et al. 2010; Franz et al. 2014; Janes et al. 2017). Furthermore, urban areas in the catchment expanded by $9 \%\left(62 \mathrm{~km}^{2}\right)$ between 1990 and 2007, with the loss of heath $(-6 \%)$ and grassland $(-3 \%)$ (Wyatt et al. 1993; Morton et al. 2011).

The annual variations based on the monthly EA monitoring data suggest a similar dominant impact of land use over hydro-climatic factors. A significant decreasing trend was observed in the mean annual SSC between 1989 and 2014, while mean annual discharge slightly increased, especially in the period after 1980 (Fig. 6). The different patterns in mean annual SSC, discharge, and precipitation could suggest that hydro-climatic factors are not the dominant driving force for long-term variation in SS transport.

Urbanization is the most significant land use change that occurred in the catchment from 1990. Despite the fact that urban street dust and other particles (e.g. from sewage treatment works) can make-up a significant part of the total SS load (Old et al. 2003; Walling et al. 2003a; Carter et al. 2003; Vercruysse and Grabowski 2019), increased urbanization could have caused a decrease in SSCs due to a decrease in the connectivity of eroding land (i.e. fragmentation of unurbanized land) and riverbanks (i.e. increase in concrete bank protection) to the river system.

In this context, the change point in 2006 could potentially be explained by soil and water conservation efforts within the catchment or major improvement works to the Esholt wastewater treatment works upstream of the point of sampling (Feather et al. 2008). However, SSCs measured during highflow events have shown that individual events can cause SSCs that are significantly higher than the annual averages (e.g. September 2016, Fig. 3b). Therefore, given that the long- 
term analysis is based on average SSCs measured monthly throughout the monitored period, it is likely that these trends and change points are influenced by individual events with high SSCs.

\subsection{Linking temporal scales of SS transport}

\subsubsection{Fractal power of SS transport}

The high temporal variability in SS transport makes it essential to develop transferable process-based approaches to quantify and predict SSCs. This study illustrates that variations in SS transport at different timescales correlate to different factors. Long-term variation in SSCs reflects changes in land use and also incorporates many processes and interactions between catchment and hydro-meteorological factors occurring at small spatial and temporal scales.

For example, based on the findings of this study, the change point observed in 2006 can be attributed to processes acting over different timescales. When considering only interannual variation in SSCs, these change points can be attributed to land management or other human activities (e.g. sewage treatment works improvements). Alternatively, the change point could also have been caused by a high-flow event flushing (bed) sediment out of the system (exhaustion) (LexartzaArtza and Wainwright 2011) or a change in channel- floodplain or channel-hillslope connectivity (Harvey 2001; Wohl et al. 2019), after which SSCs built up again over several years. Additionally, extreme events in terms of SSC such as September 2016 can strongly influence the annual average SSC (Fig. 7).

Following the results, the SS transport system in the River Aire can be characterized by high fractal power: potential long-term trends appear to be strongly influenced or masked by interactions and feedback mechanisms between catchment characteristics and hydro-meteorological conditions over shorter timescales. Even though further research will be required to explicitly model the fractal power of a SS transport system, this study has illustrated that, conceptually, the fractal approach provides a useful framework to characterize the dominant mechanisms controlling SSCs in rivers. Furthermore, the fractal power of a SS transport system has important implications for predictive modelling and transferability of methods across river systems and temporal scales. From consistent analysis of the SSCs measured in the River Aire over different timescales, it is clear that while some timescale-specific variation can be identified, the interpretation of these results in terms of driving processes is extremely difficult when only focusing on a single timescale. Individual events can be very important in controlling the annual averages, and thus, a single sediment rating curve between SSC and discharge is likely insufficient to take into account the
Fig. 7 Suspended sediment concentration (SSC) in the River Aire over three timescales: a annual (EA data; 1989-2014), b seasonal (EA and sampled data), c high-flow events (sampled data)

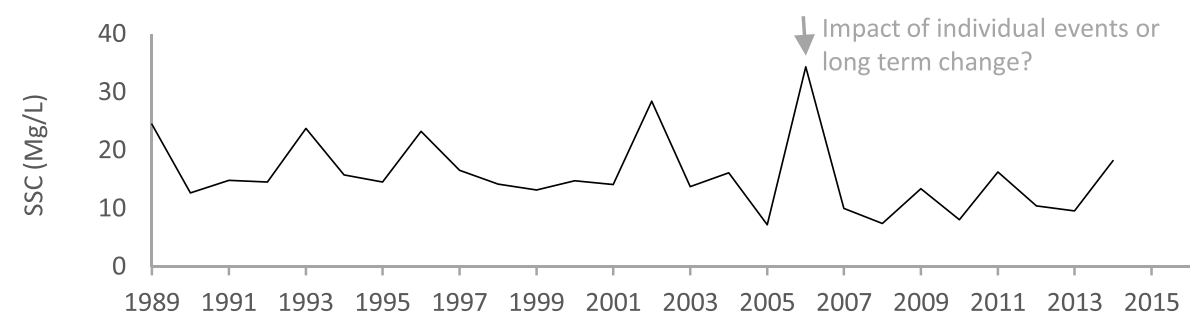

(a)

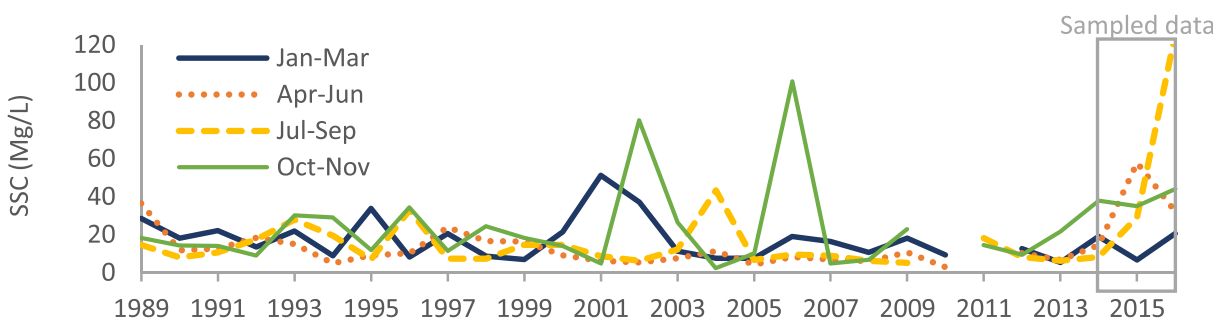

(b)

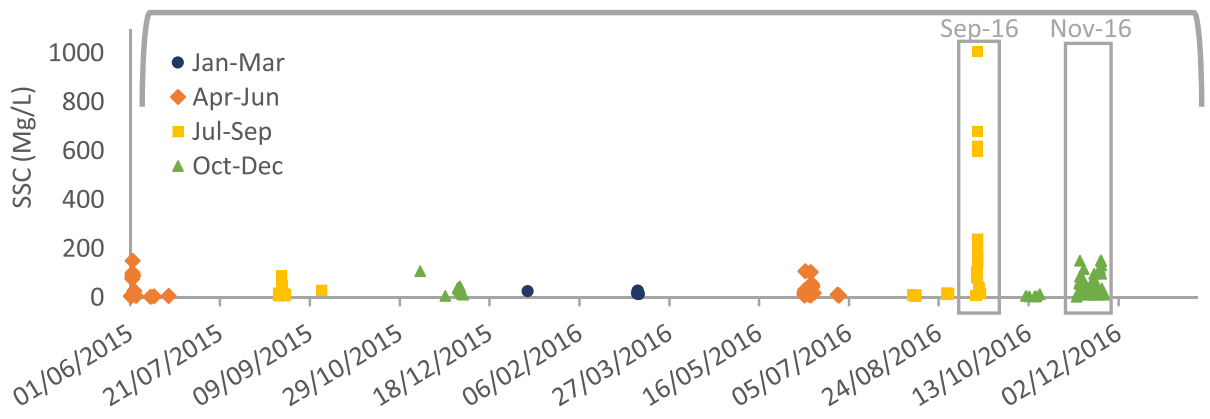


scatter around the regression line caused by temporal variability. In other words, a single rating curve would ignore the high fractal power of the SS transport system. This observation supports previous studies that have shown that SRCs based on least squares regression and monthly data underestimate sediment loads by 10-70\% (Ferguson 1985; Asselman 2000; Horowitz 2008; Skarbøvik et al. 2012). Therefore, insights into the degree of fractal power can form a useful basis to evaluate and develop the most appropriate predictive models and management strategies.

\subsubsection{Future research needs and uncertainties}

It is recognized that the results and interpretation of the presented data in terms of driving processes and fractal power are constrained by the specific study design and data sources. First, SS samples were not taken continuously during highflow events, due to site constraints that prevented deployment of a turbidity logger or autosampler, meaning important variations during the hydrograph might have been missed. This is a common limitation for SS transport research. Few monitoring networks capture high-quality, high-frequency, and longterm SSC data in rivers (i.e. water samples or calibrated turbidity at an hourly frequency or less); most collect discrete or daily SSC (e.g. USGS 2020). The authors are not aware of any high-frequency (i.e. sub-daily), continuous records that span a sufficient length of time for a multiple timescale fractal analysis. Moreover, even when autosamplers are used, the limited number of sample containers in the autosampler and the variable length of flood peaks make it difficult to consistently capture rising and falling limbs, especially over long events (Horowitz et al. 1992). The lack of a complete dataset in this study might also be an additional reason for the high predictive error associated with the PLSR model.

Second, no specific information is available on the EA SS sampling sites and the conditions during which samples were taken (e.g. change in method, change in bank protection), so that interpretation of potential change points in the data due to these changing conditions is limited. The EA datasets are the only significant collection of long-term water quality records available in the UK with nationwide coverage, but they were not designed to quantify SSC at high-flow events; the discrete, monthly samples are averaged on a rolling 3-year basis (36 samples) to characterize average water quality. Therefore, interpretation of results is affected by these uncertainties and lack of alignment between the purpose of water quality sampling and our research aims in SS transport. Again, these limitations apply to the historical water quality records of most, if not all, countries. These points emphasize the need for welldocumented, long-term, continuous SSC data in order to apply the fractal power of a SS transport system, beyond a conceptual framework, towards actual testing and modelling.

\section{Conclusion}

The SSC in the River Aire exhibits considerable inter- and intra-annual variation. By systematically comparing the variation in SS transport over multiple timescales with hydrometeorological data, the scale dependency of temporal variability in SS transport, in terms of controlling variables and mechanisms, was demonstrated. Intra- and inter-event and inter-annual variation in SSC were strongly influenced by the interplay of catchment characteristics and hydrometeorological variables. The effects of individual high-flow events on high SSCs can also influence annual variation in SSCs, thereby having a potential muting effect on factors causing long-term change in SS transport dynamics such as land use change.

To make these linkages across timescales of SS transport more explicit, SS transport in rivers can therefore be considered as a fractal system, consisting of different timescales controlled by a set of interacting processes. A fractal approach can provide a useful framework to identify the dominant mechanisms controlling SSCs in rivers and to characterize the effect of processes controlling SSC at the event scale on observed SS dynamics over longer timescales. Identifying the fractal power of a SS transport system could therefore be an appropriate starting point in developing transferrable processbased approaches to quantify and predict SSCs, as well as to develop targeted management policies. Towards this purpose, a possible road for future research would be to develop a classification system for SS transport dynamics in river systems in terms of fractal power based on the dominant processes underlying SS transport.

Acknowledgements The authors are grateful for the comments made by the reviewers and we believe that they have helped us to improve the manuscript.

Funding information This research was funded by an industrial $\mathrm{PhD}$ studentship supported by Cranfield University, Leeds City Council, and Ove Arup and Partners Limited.

Data availability Daily discharge data (1961-2015) can be downloaded through the National River Flow Archive, and monthly suspended sediment concentrations (1989-2014) can be downloaded from the Water Quality Archive from the Environment Agency. Discharge and precipitation data at a 15-min resolution is available through the Environment Agency. Suspended sediment concentrations sampled during high-flow events can be downloaded from the Cranfield Online Research Data portal (DOI: 10.17862/cranfield.rd.5903923).

Open Access This article is licensed under a Creative Commons Attribution 4.0 International License, which permits use, sharing, adaptation, distribution and reproduction in any medium or format, as long as you give appropriate credit to the original author(s) and the source, provide a link to the Creative Commons licence, and indicate if changes were made. The images or other third party material in this article are included in the article's Creative Commons licence, unless indicated otherwise in a credit line to the material. If material is not included in the 
article's Creative Commons licence and your intended use is not permitted by statutory regulation or exceeds the permitted use, you will need to obtain permission directly from the copyright holder. To view a copy of this licence, visit http://creativecommons.org/licenses/by/4.0/.

\section{References}

Ahn K-H, Yellen B, Steinscheider S (2017) Dynamic linear models to explore time-varying suspended sediment-discharge rating curves. Water Resour Res 53:5375-5377. https://doi.org/10.1002/ 2013WR014979.Reply

Aich V, Zimmermann A, Elsenbeer H (2014) Quantification and interpretation of suspended-sediment discharge hysteresis patterns: how much data do we need? Catena 122:120-129. https://doi.org/10. 1016/j.catena.2014.06.020

Alexandrov Y, Laronne JB, Reid I (2007) Intra-event and inter-seasonal behaviour of suspended sediment in flash floods of the semi-arid northern Negev, Israel. Geomorphology 85:85-97. https://doi.org/ 10.1016/j.geomorph.2006.03.013

Asselman NEM (2000) Fitting and interpretation of sediment rating curves. J Hydrol 234:228-248. https://doi.org/10.1016/S00221694(00)00253-5

Belmont P, Gran KB, Schottler SP, Wilcock PR, Day SS, Jennings C, Lauer JW, Viparelli E, Willenbring JK, Engstrom DR, Parker G (2011) Large shift in source of fine sediment in the upper Mississippi River. Environ Sci Technol 45:8804-8810. https://doi. org/10.1021/es2019109

Bilotta GS, Brazier RE (2008) Understanding the influence of suspended solids on water quality and aquatic biota. Water Res 42:2849-2861. https://doi.org/10.1016/j.watres.2008.03.018

Bilotta GS, Brazier RE, Haygarth PM (2007) The impacts of grazing animals on the quality of soils, vegetation, and surface waters in intensively managed grasslands. Adv Agron 94:237-280. https:// doi.org/10.1016/S0065-2113(06)94006-1

Bilotta GS, Burnside NG, Cheek L, Dunbar MJ, Grove MK, Harrison C, Joyce C, Peacock C, Davy-Bowker J (2012) Developing environment-specific water quality guidelines for suspended particulate matter. Water Res 46:2324-2332. https://doi.org/10.1016/j. watres.2012.01.055

Blöschl G (2006) Hydrologic synthesis: across processes, places, and scales. Water Resour Res 42:2-4. https://doi.org/10.1029/ 2005WR004319

Bracken LJ, Turnbull L, Wainwright J, Bogaart P (2015) Sediment connectivity: a framework for understanding sediment transfer at multiple scales. Earth Surf Process Landf 40:177-188. https://doi.org/ 10.1002/esp.3635

Cao Z, Li Y, Yue Z (2007) Multiple time scales of alluvial rivers carrying suspended sediment and their implications for mathematical modeling. Adv Water Resour 30:715-729. https://doi.org/10.1016/j. advwatres.2006.06.007

Carter J, Owens PN, Walling DE, Leeks GJL (2003) Fingerprinting suspended sediment sources in a large urban river system. Sci Total Environ 314-316:513-534. https://doi.org/10.1016/S00489697(03)00071-8

Carter J, Walling DE, Owens PN, Leeks GJL (2006) Spatial and temporal variability in the concentration and speciation of metals in suspended sediment transported by the River Aire, Yorkshire, UK. Hydrol Process 20:3007-3027. https://doi.org/10.1002/hyp.6156

Cobaner M, Unal B, Kisi O (2009) Suspended sediment concentration estimation by an adaptive neuro-fuzzy and neural network approaches using hydro-meteorological data. J Hydrol 367:52-61. https://doi.org/10.1016/j.jhydrol.2008.12.024
Collins AL, Walling DE, Webb L, King PL (2010) Apportioning catchment scale sediment sources using a modified composite fingerprinting technique incorporating property weightings and prior information. Geoderma 155:249-261. https://doi.org/10.1016/j.geoderma. 2009.12.008

Croke J, Fryirs KA, Thompson C (2013) Channel-floodplain connectivity during an extreme flood event: implications for sediment erosion, deposition, and delivery. Earth Surf Process Landf 38:1444-1456. https://doi.org/10.1002/esp.3430

Dominic JA, Aris AZ, Sulaiman WNA (2015) Factors controlling the suspended sediment yield during rainfall events of dry and wet weather conditions in a tropical urban catchment. Water Resour Manag 29:4519-4538

Fan X, Shi C, Zhou Y, Shao W (2012) Sediment rating curves in the Ningxia-Inner Mongolia reaches of the upper Yellow River and their implications. Quat Int 282:152-162. https://doi.org/10.1016/j. quaint.2012.04.044

Feather N, Press P, Caldwell P (2008) Yorkshire Water's large FFD scheme programme. Arup Ltd

Ferguson RI (1985) River loads underestimated by rating curves. Water Resour Res 22:0043-1397

Francke T, Lopez-Tarazon JA, Vericat D et al (2008) Flood-based analysis of high-magnitude sediment transport using a non-parametric method. Earth Surf Process Landf 33:2064-2077. https://doi.org/10. 1002/esp. 1654

Francke T, Werb S, Sommerer E, López-Tarazón JA (2014) Analysis of runoff, sediment dynamics and sediment yield of subcatchments in the highly erodible Isábena catchment, Central Pyrenees. J Soils Sediments 14:1909-1920. https://doi.org/10.1007/s11368-0140990-5

Franz C, Makeschin F, Weiß H, Lorz C (2014) Sediments in urban river basins: identification of sediment sources within the Lago Paranoá catchment, Brasilia DF, Brazil - using the fingerprint approach. Sci Total Environ 466-467:513-523. https://doi.org/10.1016/j. scitotenv.2013.07.056

Fryirs KA (2013) (Dis)connectivity in catchment sediment cascades: a fresh look at the sediment delivery problem. Earth Surf Process Landf 38:30-46. https://doi.org/10.1002/esp.3242

Gao P (2008) Understanding watershed suspended sediment transport. Prog Phys Geogr 32:243-263. https://doi.org/10.1177/ 0309133308094849

Gregory KJ (2006) The human role in changing river channels. Geomorphology 79:172-191. https://doi.org/10.1016/j.geomorph. 2006.06.018

Halley JM, Hartley S, Kallimanis AS, Kunin WE, Lennon JJ, Sgardelis SP (2004) Uses and abuses of fractal methodology in ecology. Ecol Lett 7:254-271. https://doi.org/10.1111/j.1461-0248.2004.00568.x

Harvey AM (2001) Coupling between hillslopes and channels in upland fluvial systems: implications for landscape sensitivity, illustrated from the Howgill Fells, northwest England. Catena 42:225-250

Harvey AM (2002) Effective timescales of coupling within fluvial systems. Geomorphology 44:175-201. https://doi.org/10.1016/S0169$555 \mathrm{X}(01) 00174-\mathrm{X}$

Horowitz AJ (2008) Determining annual suspended sediment and sediment-associated trace element and nutrient fluxes. Sci Total Environ 400:315-343. https://doi.org/10.1016/j.scitotenv.2008.04. 022

Horowitz AJ (2009) Monitoring suspended sediments and associated chemical constituents in urban environments: lessons from the city of Atlanta, Georgia, USA Water Quality Monitoring Program. J Soils Sediments 9:342-363. https://doi.org/10.1007/s11368-0090092-y

Horowitz AJ, Elrick KA, Von Guerard PB et al (1992) The use of automatically collected point samples to estimate suspended sediment and associated trace element concentrations for determining annual mass transport. In: Bogen J, Walling D, Day T (eds) Erosion and 
sediment monitoring programmes in river basins (Proceedings of the Oslo Symposium, August 1992), Publ. no. 210. IAHS Press, Wallingford (UK), pp 209-218

Huisman NLH, Karthikeyan KG, Lamba J, Thompson AM, Peaslee G (2013) Quantification of seasonal sediment and phosphorus transport dynamics in an agricultural watershed using radiometric fingerprinting techniques. J Soils Sediments 13:1724-1734. https://doi. org/10.1007/s11368-013-0769-0

Janes V, Nicholas A, Collins A, Quine T (2017) Analysis of fundamental physical factors influencing channel bank erosion: results for contrasting catchments in England and Wales. Environ Earth Sci 76. https://doi.org/10.1007/s12665-017-6593-x

Jiang B, Brandt S (2016) A fractal perspective on scale in geography. ISPRS Int J Geo-Information 5:95. https://doi.org/10.3390/ ijgi5060095

Karaman I, Qannari EM, Martens H, Hedemann MS, Knudsen KEB, Kohler A (2013) Comparison of sparse and jack-knife partial least squares regression methods for variable selection. Chemom Intell Lab Syst 122:65-77. https://doi.org/10.1016/j.chemolab.2012.12. 005

Kisi O (2005) Suspended sediment estimation using neuro-fuzzy and neural network approaches. Hydrol Sci J 50:683-696. https://doi. org/10.1623/hysj.2005.50.4.683

Krueger T, Quinton JN, Freer JE, Macleod CJA, Bilotta GS, Brazier RE, Butler P, Haygarth PM (2009) Uncertainties in data and models to describe event dynamics of agricultural sediment and phosphorus transfer. J Environ Qual 38:1137-1148. https://doi.org/10.2134/ jeq2008.0179

Lawler DM, Petts GE, Foster I, Harper S (2006) Turbidity dynamics during spring storm events in an urban headwater river system: the Upper Tame, West Midlands, UK. Sci Total Environ 360:109-126. https://doi.org/10.1016/j.scitotenv.2005.08.032

Lexartza-Artza I, Wainwright J (2011) Making connections: changing sediment sources and sinks in an upland catchment. Earth Surf Process Landf 36:1090-1104. https://doi.org/10.1002/esp.2134

Lloyd CEM, Freer JE, Johnes PJ, Collins AL (2016) Using hysteresis analysis of high-resolution water quality monitoring data, including uncertainty, to infer controls on nutrient and sediment transfer in catchments. Sci Total Environ 543:388-404. https://doi.org/10. 1016/j.scitotenv.2015.11.028

Lohani AK, Goel NK, Bhatia KKS (2007) Deriving stage-dischargesediment concentration relationships using fuzzy logic. Hydrol Sci J 52:793-807. https://doi.org/10.1623/hysj.52.4.793

Martens H, Martens M (2000) Modified jack-knife estimation of parameter uncertainty in bilinear modelling by partial least squares regression (PLSR). Food Qual Prefer 11:5-16. https://doi.org/10.1016/ S0950-3293(99)00039-7

McDonnell JJ, Sivapalan M, Vache K et al (2007) Moving beyond heterogeneity and process complexity: a new vision for watershed hydrology. Water Resour Res 43:1-6. https://doi.org/10.1029/ 2006WR005467

McDowell RW, Sharpley AN (2002) The effect of antecedent moisture conditions on sediment and phosphorus loss during overland flow: Mahantango Creek catchment, Pennsylvania, USA. Hydrol Process 16:3037-3050. https://doi.org/10.1002/hyp.1087

Medina-Cobo MT, Garcia-Marin AP, Estevez J, Ayuso-Munoz JL (2016) The identification of an appropriate Minimum Inter-event Time (MIT) based on multifractal characterization of rainfall data series. Hydrol Process 30:3507-3517. https://doi.org/10.1002/hyp.10875

Morgan RPC (2005) Soil Erosion \& conservation. Blackwell Publishing Ltd, Oxford

Morton D, Rowland C, Wood C, et al (2011) Final report for LCM2007 the new UK land cover map. Countryside Survey Technical Report No 11/07. Centre for Ecology and Hydrology, Natural Environment Research Council (NERC)
National River Flow Archive (2017) Daily flow data Aire at Armley. In: Environ. Agency. https://nrfa.ceh.ac.uk/data/station/info/27028

Old GH, Leeks GJL, Packman JC et al (2003) The impact of a convectional summer rainfall event on river flow and fine sediment transport in a highly urbanised catchment: Bradford, West Yorkshire. Sci Total Environ 314-316:495-512. https://doi.org/10.1016/S00489697(03)00070-6

Onderka M, Krein A, Wrede S, Martínez-Carreras N, Hoffmann L (2012) Dynamics of storm-driven suspended sediments in a headwater catchment described by multivariable modeling. J Soils Sediments 12:620-635. https://doi.org/10.1007/s11368-012-0480-6

Owens PN, Batalla RJ, Collins AJ, Gomez B, Hicks DM, Horowitz AJ, Kondolf GM, Marden M, Page MJ, Peacock DH, Petticrew EL, Salomons W, Trustrum NA (2005) Fine-grained sediment in river systems: environmental significance and management issues. River Res Appl 21:693-717. https://doi.org/10.1002/rra.878

Park E, Latrubesse EM (2014) Modeling suspended sediment distribution patterns of the Amazon River using MODIS data. Remote Sens Environ 147:232-242. https://doi.org/10.1016/j.rse.2014.03.013

Perks MT, Owen GJ, Benskin CMH et al (2015) Dominant mechanisms for the delivery of fine sediment and phosphorus to fluvial networks draining grassland dominated headwater catchments. Sci Total Environ 523:178-190. https://doi.org/10.1016/j.scitotenv.2015.03. 008

Phillips JD (2003) Sources of nonlinearity and complexity in geomorphic systems. Prog Phys Geogr 27:1-23. https://doi.org/10.1191/ 0309133303pp340ra

Pohlert T (2015) Non-parametric trend tests and change-point detection. https://www.researchgate.net/profile/Thorsten_Pohlert/publication/ 274014742_trend_Non-Parametric_Trend_Tests_and_ChangePoint_Detection_R_package_version_00 $1 / 1$ inks/ $551298 \mathrm{ec} 0 \mathrm{cf} 268 \mathrm{a} 4 \mathrm{aaea} 93 \mathrm{c} 9$.pdf?origin=publication_list

Poulenard J, Perrette Y, Fanget B, Quetin P, Trevisan D, Dorioz JM (2009) Infrared spectroscopy tracing of sediment sources in a small rural watershed (French Alps). Sci Total Environ 407:2808-2819. https://doi.org/10.1016/j.scitotenv.2008.12.049

Raven EK, Lane SN, Bracken LJ (2010) Understanding sediment transfer and morphological change for managing upland gravel-bed rivers. Prog Phys Geogr 34:23-45. https://doi.org/10.1177/ 0309133309355631

Rickson RJ (2014) Can control of soil erosion mitigate water pollution by sediments? Sci Total Environ 468-469:1187-1197. https://doi.org/ 10.1016/j.scitotenv.2013.05.057

Rodriguez-Iturbe I, Rinaldo A (2001) Fractal river basins: chance and self-organization, Revised. Cambridge University Press, Cambridge

Rovira A, Ibáñez C, Martín-Vide JP (2015) Suspended sediment load at the lowermost Ebro River (Catalonia, Spain). Quat Int 388:188-198. https://doi.org/10.1016/j.quaint.2015.05.035

Seeger M, Errea MP, Beguería S et al (2004) Catchment soil moisture and rainfall characteristics as determinant factors for discharge/ suspended sediment hysteretic loops in a small headwater catchment in the Spanish pyrenees. J Hydrol 288:299-311. https://doi.org/10. 1016/j.jhydrol.2003.10.012

Sherriff SC, Rowan JS, Fenton O, Jordan P, Melland AR, Mellander PE, hUallacháin DÓ (2016) Storm event suspended sediment-discharge hysteresis and controls in agricultural watersheds: implications for watershed scale sediment management. Environ Sci Technol 50: 1769-1778. https://doi.org/10.1021/acs.est.5b04573

Sivakumar B (2001) Is a chaotic multi-fractal approach for rainfall possible? Hydrol Process 15:943-955. https://doi.org/10.1002/hyp.260

Skarbøvik E, Stålnacke P, Bogen J, Bønsnes TE (2012) Impact of sampling frequency on mean concentrations and estimated loads of suspended sediment in a Norwegian river: implications for water management. Sci Total Environ 433:462-471. https://doi.org/10. 1016/j.scitotenv.2012.06.072 
Skøien JO, Blöschl G, Western AW (2003) Characteristic space scales and timescales in hydrology. Water Resour Res 39. https://doi.org/ 10.1029/2002WR001736

Smith HG, Dragovich D (2009) Interpreting sediment delivery processes using suspended sediment-discharge hysteresis patterns from nested upland catchments, south-eastern Australia. Hydrol Process 23: 2416-2426. https://doi.org/10.1002/hyp

Stevens A, Lopez LR (2015) A guide to diffuse reflectance spectroscopy $\&$ multivariate calibration with the R statistical software. Katholieke Universiteit Leuven, Leuven

Sun L, Yan M, Cai Q, Fang H (2016) Suspended sediment dynamics at different time scales in the Loushui River, south-central China. Catena 136:152-161. https://doi.org/10.1016/j.catena.2015.02.014

Tananaev NI (2015) Hysteresis effects of suspended sediment transport in relation to geomorphic conditions and dominant sediment sources in medium and large rivers of the Russian Arctic. Hydrol Res 46:232243. https://doi.org/10.2166/nh.2013.199

Taylor KG, Owens PN (2009) Sediments in urban river basins: a review of sediment-contaminant dynamics in an environmental system conditioned by human activities. J Soils Sediments 9:281-303. https://doi.org/10.1007/s11368-009-0103-z

Tena A, Vericat D, Batalla RJ (2014) Suspended sediment dynamics during flushing flows in a large impounded river (the lower River Ebro). J Soils Sediments 14:2057-2069. https://doi.org/10.1007/ s11368-014-0987-0

USGS (2020) USGS Sediment Data Portal. https://cida.usgs.gov/ sediment/\#. Accessed 16 Mar 2020

Van Nieuwenhuyse BHJ, Antoine M, Wyseure G, Govers G (2011) Pattern-process relationships in surface hydrology: Hydrological connectivity expressed in landscape metrics. Hydrol Process 25: 3760-3773. https://doi.org/10.1002/hyp.8101

Vanmaercke M, Ardizzone F, Rossi M, Guzzetti F (2016) Exploring the effects of seismicity on landslides and catchment sediment yield: an Italian case study. Geomorphology. 278:171-183. https://doi.org/ 10.1016/j.geomorph.2016.11.010

Vercruysse K, Grabowski RC (2019) Temporal variation in suspended sediment transport: linking sediment sources and hydrometeorological drivers. Earth Surf Process Landforms esp.4682. https://doi.org/10.1002/esp.4682

Vercruysse K, Grabowski RCRC, Rickson RJ (2017) Suspended sediment transport dynamics in rivers: multi-scale drivers of temporal variation. Earth-Science Rev 166:38-52. https://doi.org/10.1016/j. earscirev.2016.12.016
Walling DE (2009) The impact of global change on erosion and sediment transport by rivers: current progress and future challenges. Paris

Walling DE, Owens PN, Carter J, Leeks GJL, Lewis S, Meharg AA, Wright J (2003a) Storage of sediment-associated nutrients and contaminants in river channel and floodplain systems. Appl Geochem 18:195-220. https://doi.org/10.1016/S0883-2927(02)00121-X

Walling DE, Owens PN, Foster IDL, Lees JA (2003b) Changes in the fine sediment dynamics of the Ouse and Tweed basins in the UK over the last 100-150 years. Hydrol Process 17:3245-3269. https://doi. org/10.1002/hyp.1385

Wohl E (2015) Legacy effects on sediments in river corridors. EarthScience Rev 147:30-53. https://doi.org/10.1016/j.earscirev.2015. 05.001

Wohl E, Brierley G, Cadol D, Coulthard TJ, Covino T, Fryirs KA, Grant G, Hilton RG, Lane SN, Magilligan FJ, Meitzen KM, Passalacqua P, Poeppl RE, Rathburn SL, Sklar LS (2019) Connectivity as an emergent property of geomorphic systems. Earth Surf Process Landf 44:4-26. https://doi.org/10.1002/esp.4434

Wold S, Sjostrom M, Eriksson L (2001) PLS-regression: a basic tool of chemometrics. Chemom Intell Lab Syst 58:109-130

Wyatt BK, Greatorex-Davies NG, Bunce RGH, et al (1993) Comparison of land cover definitions. Countryside 1990 Series: Volume 3. London

Zeiger S, Hubbart JA (2016) Quantifying suspended sediment flux in a mixed-land-use urbanizing watershed using a nested-scale study design. Sci Total Environ 542:315-323. https://doi.org/10.1016/j. scitotenv.2015.10.096

Zhang S, Lu XX (2009) Hydrological responses to precipitation variation and diverse human activities in a mountainous tributary of the lower Xijiang, China. Catena 77:130-142. https://doi.org/10.1016/j. catena.2008.09.001

Zhang S, Mao X (2015) Hydrology, sediment circulation and long-term morphological changes in highly urbanized Shenzhen River estuary, China: a combined field experimental and modeling approach. J Hydrol 529:1562-1577. https://doi.org/10.1016/j.jhydrol.2015.08. 027

Zhang W, Yan Y, Zheng J, Li L, Dong X, Cai H (2009) Temporal and spatial variability of annual extreme water level in the Pearl River Delta region, China. Glob Planet Chang 69:35-47. https://doi.org/ 10.1016/j.gloplacha.2009.07.003

Publisher's note Springer Nature remains neutral with regard to jurisdictional claims in published maps and institutional affiliations. 